\title{
O Seguro Social e a Construção da Proteção do Trabalho no Brasil*
}

\author{
Arnaldo Provasi Lanzara \\ Universidade Federal Fluminense, Rio de Janeiro, RJ, Brasil. E-mail: prolanzara@gmail.com
}

\section{INTRODUÇÃO}

$\mathrm{O}$ seguro social designa muito mais do que uma forma de proteção da renda, guardando um profundo significado político e associativo. Tal significado, contudo, não deixa de ser a expressão das transformações que afetaram o mundo popular, desde o momento em que as diversas formas de organização coletiva dos trabalhadores foram admitidas na comunidade política. A bem dizer, o trabalho e o seguro social sofreram uma transformação semântica ao se referenciarem em conceitos propriamente políticos que ressignificaram a noção de espaço público e de direitos do homem, alterando o sentido da ação política através de um tipo de ação coletiva identificadora de direitos sociais.

Alinhando-se a importantes trabalhos que enfatizaram a presença do Estado brasileiro na criação dos estatutos de proteção social, este estudo se propõe a demonstrar como o seguro social referenciou a ação coletiva dos trabalhadores brasileiros, durante as décadas de 1930 e 1940, ao estruturar os recursos simbólicos e materiais das proteções que tipificaram a sociedade do trabalho no Brasil. Apesar de rarefeitas, essas proteções foram constitutivas de um arranjo político-normativo que, mesmo mitigado pelas estratégias patronais de subversão dos instru-

*Este trabalho é desdobramento de uma tese de doutorado defendida no IESP-UERJ, em 2012, intitulada: A Construção Histórica do Estado Social no Brasil e no Chile: do mutualismo ao seguro, sob orientação de Renato Boschi. Agradeço os valiosos comentários de Cesar Guimarães, Eli Diniz, Maria Regina Soares de Lima e Gilberto Hochman.

DADOS - Revista de Ciências Sociais, Rio de Janeiro, vol. 61, n-2, 2018, pp. 463 a 502.

http://dx.doi.org/10.1590/001152582018158 
mentos de regulação do trabalho, tornou atrativo para os trabalhadores o seu engajamento profissional.

A hipótese a ser aventada, neste artigo, é que a legislação do seguro social criou, primeiramente e de um modo não premeditado, as condições para o advento do instituto da estabilidade do trabalhador no emprego (que vigorou no país de 1943 a 1966), e secundariamente e de forma propositada, as bases de adensamento do processo de sindicalização. Tal hipótese encontra justificativa ao se analisar os diferentes modos pelos quais os responsáveis por implementar a política social e trabalhista, nas décadas de 1930 e 1940, mobilizaram os benefícios do seguro, como estratégia de indução institucional, para criar as condições de concretização dos direitos sociais no país.

O artigo está dividido em sete seções além desta introdução. A segunda seção discorre brevemente sobre a transformação histórica do seguro social, ressaltando as mudanças por ele engendradas ao modificar o sentido dos conceitos de salário, propriedade e de contrato social. A terceira seção remonta as origens privadas do seguro social no Brasil, durante o liberalismo oligárquico da Primeira República (1891-1930), ao se analisar os modos de organização das sociedades de benefícios mútuos paulistas que serviram de modelo para a criação das Caixas de Aposentadorias e Pensões (CAPs) em 1923. A quarta seção trata da utilização do seguro social pelas elites estatais brasileiras, após a Revolução de 1930, como estratégia de adensamento coletivo das instituições do mundo do trabalho, especialmente dos sindicatos. A quinta seção destaca a vinculação entre seguro social, sindicatos e Justiça do Trabalho no momento de consolidação da legislação trabalhista e do instituto da estabilidade no trabalho durante o período do Estado Novo (1937-1945). A sexta seção demonstra como alguns intelectuais do período, engajados nos temas da proteção do trabalho, a exemplo de Oliveira Vianna, concebiam o papel do seguro social na sociedade brasileira, destacando suas possibilidades e limitações. A sétima e última seção conclui o trabalho.

\section{DO MUTUALISMO AO SEGURO SOCIAL: DAS PROTEÇÕES PATRONAIS TUTELARES A UM NOVO CONTRATO SOCIAL}

As origens do seguro social remontam as primeiras sociedades de benefícios mútuos. Desde o início do século XIX, essas sociedades surgiram em resposta ao industrialismo e ao consequente processo de desti- 
tuição do trabalho dos seus antigos suportes de proteção. Tais iniciativas de "ajuda mútua" foram, em parte, uma reação dos trabalhadores à "ofensiva civilizatória" da burguesia sobre os seus modos de vida (Thompson, 1968).

Porém, algumas dessas sociedades também podem ser consideradas como organizações configurativas de uma psicogênese orientada a reproduzir as exclusões típicas do mundo do mercado (Swann, 1988, 2005). Em muitos aspectos, elas demonstraram ser passíveis a uma regularidade sociológica, cristalizando um sistema de pequenas unidades autônomas de provisão de benefícios - que incluía grupos com características mais homogêneas -, sempre propenso a excluir os diferentes, os grupos de baixa renda, do consumo desses benefícios.

Não é casual o fato de essas sociedades terem proliferado num período em que o Estado se omitia em regular as condições de trabalho. A recusa obstinada dos liberais do século XIX em elaborar políticas assistenciais de caráter público, e de fazer da assistência uma questão de direito, legitimava as práticas voluntárias de beneficência. O corolário disso, segundo François Ewald (1986:75), foi uma abordagem do social que encontrou respaldo no direito contratual privado e na ideia de tutela: "a relação do pobre com o seu benfeitor é uma relação moral e está aquém da esfera do direito".

No final do século XIX, o patronato industrial passou a perceber, nessas mutuais, os instrumentos de que necessitava para fixar e disciplinar a mão de obra nas indústrias, em resposta ao intenso movimento de mobilidade do trabalho. Com o controle dos recursos simbólicos e materiais dessas associações, o patronato poderia diretamente disciplinar a produção, evitando assim a intromissão dos regulamentos públicos de proteção do trabalho no interior das indústrias. Ademais, as virtudes morais do mutualismo relatadas à autocompulsão dos trabalhadores para se tornarem "indivíduos proprietários" poderiam aqui cumprir uma função de utilidade para o próprio processo acumulativo.

As ambiguidades que envolveram o processo de constituição dos primeiros arranjos mutualistas de proteção não escaparam à argúcia preditiva de alguns pensadores do século XIX. Em resposta aos problemas sociais do seu tempo, Alexis de Tocqueville advogava que o futuro reservaria um importante papel para as caixas de poupança - antevendo, nesse sentido, um processo de fusão das associações mutualistas e de beneficência -, mas com a condição de que essas caixas fossem trans- 
formadas em instituições de apoio ao espírito de "previdência" dos mais pobres. Com essas caixas, dizia o pensador francês, a pobreza deixaria de ser um problema para o porvir das sociedades, especialmente se o "pobre", com o concurso de novas ideias e costumes, lograsse com o fruto do seu trabalho criar um lenitivo às misérias de outros pobres, construindo um dique entre o seu futuro e a incerteza, através das virtudes da propriedade e do associativismo (Tocqueville, 1989 [1835]).

O vaticínio tocquevilliano sobre o advento da democracia e do Estado social, com todas as contradições que presidiam ambos os fenômenos, deixava pistas sobre o futuro reservado às instituições do seguro:

À medida que os homens se misturam e que as condições se igualam, o pobre
tem mais recursos, luzes e desejos. Ele concebe a idéia de melhorar sua sorte e
tenta consegui-lo por meio da poupança. A poupança faz nascer, portanto, cada
dia, um número infinito de pequenos capitais, frutos lentos e sucessivos do tra-
balho, que crescem sem cessar [...]Isso deu nascimento a uma instituição filan-
trópica que não tardará a se tornar, ou muito me engano, uma de nossas maio-
res instituições políticas (Tocqueville, 2000 [1840]:378).

Contudo, a ideologia da modernidade capitalista revelaria que a independência do indivíduo somente se constrói através da aquisição da propriedade - acoplada, é claro, a um Estado de direito que garanta à sua segurança jurídica. Esta construção levantou a questão do estatuto, ou da falta de estatuto, do indivíduo não proprietário. No bojo das soluções esboçadas ao problema da destituição, a questão social irá descobrir que, "numa sociedade que se reorganiza em torno da condição salarial, é o estatuto conferido ao trabalho que produz o homólogo moderno das proteções tradicionalmente asseguradas pela propriedade" (Castel, 1998:387).

De fato, nas sociedades modernas, em que os recursos são alocados de forma complexa, o que conta é cada vez menos o que cada um possui enquanto "indivíduo proprietário" e cada vez mais os direitos que são adquiridos pelo grupo social ao qual se pertence (Hatzfeld, 1982:49). Assim, a poupança particular ou o próprio capital acumulado individualmente teria menos importância do que o estatuto coletivo definido por um conjunto de direitos sociais. Em outras palavras, os trabalhadores não proprietários dos meios de produção passaram a ser "proprietários de direitos" enquanto beneficiários das proteções sociais (Castel e Haroche, 2001; Castel, 2003). Fundamental para esta mu- 
dança semântica da noção de propriedade foi o advento do seguro social público.

De acordo com Ewald (1990), o seguro social surge para designar um conjunto de instituições e ao mesmo tempo o princípio mediante o qual as sociedades pensam a sua própria organização coletiva. Pode-se dizer que as sociedades se tornam modernas quando o esquema do seguro materializa o imaginário do contrato social. Através de suas técnicas e de suas instituições, o seguro social informa a sociedade sobre a natureza social dos seus vínculos, transformando o próprio modo de agir do Estado. Com o seguro, o Estado passa a registrar os conflitos e as divisões da sociedade e a se envolver num processo de coletivização dos riscos. ${ }^{1}$

O seguro social, enfim, se assenta numa justiça contratual em que a ordem das convenções coletivas substitui a ordem naturalizada das desigualdades e dos riscos individuais (Ewald, 1990). Tome-se o exemplo do seguro de acidentes de trabalho. Antes que esse seguro se tornasse obrigatório na legislação social de diversos países, na última década do século XIX, prevalecia a ideia liberal de que a distribuição dos bens e dos males sociais era em si mesma justa. Tal distribuição deveria ser deixada ao livre jogo do acaso. Neste mundo, sofrer um infortúnio, como um acidente de trabalho, não conferia qualquer direito à vítima, e a responsabilidade individual pelo dano era o mais perfeito princípio regulador das ações humanas. A invenção da ideia de risco profissional, ao contrário, consiste em pensar um princípio de imputação que, liberado das velhas dependências da natureza, transforma a incidência individual ao risco em uma "responsabilidade coletiva" (Ewald, 1992:15). O que sai de cena com o advento dessa ideia é o exame das condutas individuais, que é substituído pela apreciação dos fatos sociais geradores dos infortúnios: a regularidade do risco torna-se então independente da conduta do indivíduo.

Portanto, o que distingue o seguro social das antigas formas mutualistas e individuais de proteção, incluindo as proteções patronais paternalistas, é que ele permite consagrar uma repartição social dos riscos não mais fundamentada na caridade e na culpa, mas segundo uma regra de direito.

Do ponto de vista das ideias, o período que preside essa transformação do mutualismo ao seguro é marcado pelo nascimento de um novo paradigma: o "paradigma solidarista", que vem contestar e substituir a

DADOS - Revista de Ciências Sociais, Rio de Janeiro, vol. 61, nº 2, 2018 
noção de responsabilidade individual do liberalismo. O solidarismo, como doutrina da repartição coletiva das responsabilidades e dos riscos sociais, junto ao direito público que o consubstanciou, foi fortemente valorizado por alguns juristas e reformadores sociais no fim do século XIX e no início do século XX, informando as principais diretrizes a serem adotadas pelas instituições coletivas do seguro. O modelo de sociedade pensado a partir do paradigma solidarista não era estritamente o de uma sociedade de cidadãos formalmente "livres e iguais", mas o de uma "sociedade de semelhantes". Uma sociedade que, segundo Léon Burgueois (1896), é "diferenciada e hierarquizada", mas na qual todos os seus membros podem manter relações entre si, compartilhando obrigações e direitos comuns, pois "os homens já nascem devedores da sociedade" (Burgueois, 1896: 53).

O solidarismo ainda conferia ao Estado uma função reguladora no que dizia respeito aos interesses das coletividades. Através de uma nova "episteme solidária" (Ewald, 1986), o Estado social promoveria os interesses coletivos com a expansão dos direitos sociais. Estes, por sua vez, se instituiriam como força de coordenação de uma multiplicidade de serviços públicos e sociais, conferindo um "rosto sensível" à diversidade de interesses coletivos que se interpunham às generalizações abstratas do liberalismo fundadas num hipotético "interesse geral" (Rosanvallon, 2008:74).

Entretanto, o seguro social ainda levaria muito tempo para se desvencilhar das heranças do mutualismo e das proteções tutelares exercidas pelo patronato que marcaram o período liberal. É somente no imediato pós-Segunda Guerra que se colocará em prática, em uma série de países, a ideia de transformar o seguro em um conjunto de prestações sociais integrais. O advento de uma "seguridade social", designando o conjunto dessas prestações, também iria modificar as tradicionais relações de assalariamento. Com a seguridade social, o salário não seria mais concebido como uma remuneração do trabalho estritamente calculada para garantir a reprodução do trabalhador e de sua família. A seguridade comportaria uma parte do salário, o chamado "salário indireto", constituindo-se como uma renda do trabalho para situações "fora do trabalho", que dentro de certos limites "desmercantiliza" a relação puramente salarial (Castel 1998:405).

Ainda mais importante é o fato de a seguridade social extrapolar sua função estritamente econômica ao se constituir como um direito fun- 
damental nas sociedades que a promoveram. Nesse aspecto, o direito à seguridade social fundamentou-se numa experiência de reciprocidade com relação ao que o público dele esperava cognitiva e normativamente, cumprindo um importante papel para a integração das expectativas da sociedade nas proteções jurídicas que legitimaram o Estado social (Luhmann, 1983). É nessa experiência de reciprocidade que esse direito estruturou sua síntese regulativa.

O contrato social que a seguridade social legitimou tornar-se-ia, portanto, parte do chamado "compromisso cívico-industrial" de construção de um novo espaço público, voltado tanto para os interesses do trabalho como para os interesses da república; um compromisso entre o particular e o geral; entre o "ser coletivo", que não pode ser confundido como uma "coleção de indivíduos", e a nação em sua totalidade (Boltanski e Thévenot, 2006:232).

Enfim, a função protetora do seguro social mostrou-se fundamental para estabilizar as expectativas dos assalariados quanto à manutenção das condições de sua independência social, constituindo-se numa propriedade para a segurança das coletividades fortemente imbricada à ideia de pertencimento coletivo. Nas próximas seções se discutirá como essa função protetora e associativa do seguro social cumpriu um importante papel em sociedades estruturalmente desiguais, como a brasileira, marcadas por uma rarefação de instrumentos de regulação pública do trabalho.

\section{O MUTUALISMO EMPRESARIAL PAULISTA E AS ORIGENS DO SEGURO SOCIAL NO BRASIL}

Pouca atenção é dedicada ao fenômeno do mutualismo nos estudos sobre a emergência do seguro social no Brasil. Ao tomarem precipitadamente o momento legislativo do "Estado paternalista" como marco inicial das iniciativas de proteção no âmbito da previdência social (Malloy, 1976,1986), esses estudos tendem a desconsiderar as formas de proteção societárias que antecederam e influenciaram a primeira legislação previdenciária brasileira: a célebre Lei no 4.682, que instituiu as Caixas de Aposentadoria e Pensões (CAPs) em 1923. Poucos autores se deram conta de que essa legislação exprimiu, de certo modo, as exclusões tipificadas pelo modo de produção de políticas do liberalismo oligárquico ao se fundamentar nas estratégias empresarias mutualis-

DADOS - Revista de Ciências Sociais, Rio de Janeiro, vol. 61, n’ 2, 2018 
tas que proliferaram no seio do patronato industrial paulista durante a Primeira República (1889-1930).

É sabido que durante esse período a classe operária brasileira permaneceu como "força isolada no mercado", ausente de reconhecimento político e legal (Werneck Vianna, 1999 [1976]: 79). A Constituição liberal de 1891 não reconhecia o caráter estatutário das profissões: “arcaico eco do ideário anticorporativo do século XVIII" (Santos, 1979:19), e que fazia jus à construção de uma ordem republicana, uma ordem puramente contratual, sem ingerência das associações do mundo do trabalho.

É em reação a esse não reconhecimento que as mutuais brasileiras nascem imbricadas à ideia de valorização moral do trabalhador. Essa valorização tornou-se um aspecto crucial da estratégia dos próprios trabalhadores em suas lutas para que o reconhecimento dos seus direitos associativos adquirisse expressão política e legal.

Apesar de as mutuais brasileiras servirem, em princípio, aos interesses dos trabalhadores, várias dessas sociedades eram entidades fundadas pelo patronato industrial e de empresas dos setores de serviços ligados ao complexo primário-exportador e financeiro (Luca, 1990).

Nesse aspecto, é importante salientar as principais diferenças existentes entre as mutuais do Rio de Janeiro e de São Paulo durante a Primeira República. Se as semelhanças entre o mutualismo dos respectivos estados devem ser buscadas no conjunto de práticas associativas que geraram solidariedades horizontais entre os trabalhadores, suas diferenças, contudo, decorrem de como essas solidariedades se defrontaram com diferentes formas de apropriação dos recursos simbólicos e materiais de sua organização.

O perfil ocupacional da cidade do Rio de Janeiro e os modos de organização do proletariado, entre fins do século XIX e início do século XX, eram bastante distintos daqueles que prevaleciam em São Paulo. ${ }^{2}$ As mutuais existentes no Rio de Janeiro, especialmente as mutuais organizadas por algumas categorias ligadas às atividades do Estado, desenvolveram fortes afinidades com o nascente movimento sindical. As organizações mutualistas se apresentavam como os únicos espaços disponíveis aos trabalhadores que quisessem se organizar politicamente para pleitear reconhecimento profissional junto ao Estado (Batalha, 1999). 
A grande quantidade de empregos públicos existentes na cidade do Rio de Janeiro, então capital da República, fez proliferar as mutuais ligadas ao funcionalismo público. ${ }^{3}$ A ação política dessas mutuais foi crucial para encaminhar ao Estado um conjunto de leis que visavam garantir proteção e estabilidade para o funcionário público no cargo. Tal estabilidade se afigurava como único recurso para o Estado fazer valer suas decisões jurídicas e administrativas, sobretudo em razão da existência de certas tendências privatistas de dispersão e autonomização do poder territorial que prevaleceram durante o liberalismo oligárquico (1891-1930).

De modo a escapar desse assédio privatista, o Estado brasileiro criou importantes regulamentos que consignavam disposições assecuratórias para a permanência do funcionalismo público no cargo (Luca, 1990). Tais disposições visavam proteger os funcionários contra demissões arbitrárias, tornando os cargos públicos mais atrativos para aqueles que buscavam um emprego estável e relativamente protegido. Entrar no serviço público representava um modo seguro de escapar do emprego no setor privado, que numa ordem liberal oligárquica significava subordinar-se ao livre arbítrio do patronato. Entrar no serviço público, portanto, significava a certeza da estabilidade no trabalho.

Vale ressaltar que a normatização precoce de um conjunto de leis de caráter previdenciário no Brasil, destinado a proteger o funcionalismo, revelou-se essencial para estabelecer as diferenças entre os tipos de emprego existentes nos setores público e privado. Tais diferenças não podem ser vistas exclusivamente segundo a ótica dos "privilégios injustificáveis" concedidos clientelisticamente pelo "Estado patrimonialista" para favorecer determinadas categorias (Malloy, 1986). ${ }^{4}$

Os dispositivos de regulamentação do trabalho e de proteção securitária destinados ao funcionalismo, especialmente os que asseguravam estabilidade no trabalho, serviram como importantes fixadores das expectativas daqueles que dependiam exclusivamente das precárias condições que vigiam no mercado privado de trabalho. Ee sintomático o fato de os trabalhadores do Rio de Janeiro terem percebido, precocemente, a importância do reconhecimento profissional pelo Estado como uma estratégia de defesa dessa estabilidade tanto almejada.

Situação bastante distinta era a das mutuais organizadas em São Paulo. As entidades patrocinadas pelos empresários representavam um importante grupo no universo das mutuais paulistas. Na ausência de

DADOS - Revista de Ciências Sociais, Rio de Janeiro, vol. 61, nº 2, 2018 
regulação das condições de trabalho, as mutuais organizadas por empresa possuíam, como principal característica, o fato de se organizarem para impedir o livre estabelecimento das associações dos trabalhadores.

É importante lembrar que no Brasil da Primeira República havia certo monopólio patronal nas discussões que cercavam o tema da regulamentação das condições de trabalho (Castro Gomes, 1979; Werneck Vianna, 1999[1976]). O compromisso dilatório do Estado liberal oligárquico, em relação às medidas mais abrangentes de regulação do processo acumulativo, tinha, para a prática empresarial do período, uma consequência eficaz, constituindo-se no tempo hábil de que o empresariado necessitava para protelar e modificar as leis de proteção do trabalho. Enfim, era o tempo de que o empresariado necessitava para introduzir suas próprias medidas privadas e paternalistas de proteção no interior das companhias. Mesmo beneficiado pelas altas taxas de acumulação na indústria, o patronato brasileiro, especialmente o patronato paulista, reclamava constantemente que a oferta efetiva de trabalho, desde sempre disponível, não representava ganhos de produção e competitividade, dada a baixa qualificação dos trabalhadores empregados na indústria e o reduzido tempo pelo qual um trabalhador permanecia num mesmo emprego. ${ }^{5}$

É neste contexto que se enquadra o surgimento das mutuais patronais paulistas como solução para o problema da fixação de mão de obra na indústria. Nessa modalidade de sociedade de benefício mútuo, o proprietário de indústria, ou presidente de companhia ligada ao setor de serviços, criava uma sociedade beneficente em seu estabelecimento e obrigava os empregados a filiarem-se nela (Luca, 1990:24).

O conjunto de benefícios oferecidos por essas entidades dava a impressão de que o patronato industrial se dispunha a ceder um considerável espaço de negociação ao trabalho no interior das companhias. No entanto, os regulamentos e as distinções atribuídas pelo patronato para destacar com benefícios diferenciados os trabalhadores mais engajados nos valores da companhia cumpriam uma dupla função: por um lado, "impediam que os operários controlassem os destinos das mutuais", por outro, "evitavam uma sobrecarga dos cofres sociais das entidades" (idem: 56).

A utilização arbitrária dos fundos mútuos pelo patronato era fortemente criticada pelos trabalhadores. Eram frequentes as acusações de 
que os empresários, "patrocinadores" desses fundos, desviavam a finalidade das mutuais ao estabelecerem seus próprios critérios de administração e de aplicação das reservas técnicas dos fundos mútuos para finalidades meramente especulativas. Poucas associações desse tipo ousavam tocar nos assuntos referentes às condições de trabalho, sob o risco de sofrerem fortes sanções do patronato. Ademais, tal ingerência representava uma forma de apropriação dos recursos simbólicos e organizativos da classe operária, pois o controle patronal dos fundos associativos quebrava as solidariedades horizontais estabelecidas entre os trabalhadores, criando, no interior das companhias, formas hierárquicas e competitivas de obtenção de benefícios sociais.

Assim, nas mutuais submetidas ao controle empresarial, apenas os grupos que, em princípio, cumprissem com as contribuições exigidas pelas companhias, e que se identificassem com os "valores éticos" das mesmas, poderiam participar dos seus quadros dirigentes. A "identidade" do grupo na qual a mutual estava filiada, neste caso, era a identidade fabricada pelo supervisor da empresa.

Cabe realçar que, sob esta modalidade de controle patronal dos fundos mútuos, dificilmente o associativismo operário poderia alcançar uma dimensão mais reivindicativa no sentido de converter esses fundos em importantes recursos de ação coletiva para lutar pela conquista de novos direitos. Disso decorre a negligência dos temas vinculados à questão da regulação das condições de trabalho por parte dessas mutuais, e seu consequente afastamento das demandas do movimento operário mais combativo. ${ }^{6}$

As mutuais empresariais paulistas serviram de modelo para a criação das Caixas de Aposentadoria e Pensões (CAPs) em 1923. Os dirigentes das companhias paulistas, especialmente os das estradas de ferro ligadas ao complexo primário-exportador, viam, nas Caixas organizadas por empresa, a solução para o problema do aumento dos encargos e passivos acumulados pelos fundos mútuos. Tal solução foi adotada em função da impossibilidade de esses fundos arcarem sozinhos com as despesas relativas ao pagamento de pensões e outros auxílios, principalmente os auxílios médicos, e da necessidade de aplicar os saldos das reservas técnicas das mutuais em atividades mais vantajosas para as empresas.

Vale ainda ressaltar o fato de o instituto da estabilidade no emprego, que vigorou no país de 1943 a 1966, nascer vinculado às necessidades

DADOS - Revista de Ciências Sociais, Rio de Janeiro, vol. 61, nº 2, 2018 
atuariais no campo do seguro social. A garantia de um fluxo contínuo de contribuições para a solvência financeira das CAPs demandava a permanência do trabalhador no emprego. O artigo 53 da Lei que estabeleceu as Caixas, em 1923, assim previa:

Após dez anos de serviço prestado a mesma empresa, os empregados a que se refere a presente lei só poderão ser demitidos em caso de falta grave, apurada em inquérito feito pela administração da empresa, ouvido o acusado por si ou com assistência do seu advogado ou do advogado do sindicato da classe ou do representante do mesmo, se houver, cabendo recurso para o Conselho Nacional do Trabalho (Brasil, 1923).

Portanto, de modo a inibir a rotatividade no emprego, o patronato industrial, no início da legislação social, apostou no controle dos fundos do seguro social para recrutar mão de obra num contexto de mobilidade desregulamentada da força de trabalho. Assim, devido à escassez de trabalho qualificado, a estabilidade no posto de trabalho era requisitada pelo patronato, na ocasião, para garantir um fluxo contínuo de contribuições dos trabalhadores às CAPs e para assegurar sua permanência nas empresas.

Em suma, a legislação previdenciária de 1923 conferiu reconhecimento legal às modalidades empresariais e tutelares de proteção, deturpando a função pública e coletiva do seguro no seu nascimento. A legitimidade da norma, aqui, emanava das práticas que prevaleciam no chão de fábrica. O problema em torno das CAPs referia-se à sua estrutura de funcionamento, que praticamente cedia aos empregadores a prerrogativa de instituir os fundos de proteção da classe trabalhadora, colocando diversos óbices à expansão dos benefícios do seguro para as categorias profissionais. Como se verá a seguir, é somente com advento das mudanças no modo de agir do Estado em relação à questão da regulamentação das condições de trabalho, promovidas pela Revolução de 1930, que se produzirá a expansão do seguro para as categorias profissionais, - o que contribuiu para retirá-lo da tutela das empresas, colocando-o sob a órbita do Estado.

\section{A CRIAÇÃO DO SEGURO SOCIAL PROFISSIONAL E O ADENSAMENTO DOS SINDICATOS}

A importância do seguro social no Brasil reside menos na abrangência dos seus benefícios e mais na função que ele desempenhou ao estruturar as condições para o advento dos estatutos de proteção do trabalho. 
Para compreender os intrincados relacionamentos que presidiram a formação do sistema de proteção social brasileiro, é necessário ter em conta o inter-relacionamento complexo entre trabalho e seguro social. Um inter-relacionamento que adquire contornos mais nítidos durante as décadas de 1930 e 1940 com o advento do regime corporativo implementado durante o primeiro governo de Getúlio Vargas (1930-1945).

O modelo corporativo brasileiro reordenou as relações entre o público e o privado, sendo capaz, nesse sentido, de modificar minimamente os recursos de organização das coletividades por intermédio da legislação social. Porém, seu modo de operação foi bastante contraditório, mostrando-se insuficiente para alterar os padrões de distribuição dos recursos - os padrões propriamente redistributivos - e assim de reprodução das desigualdades. No âmbito próprio da política social e trabalhista, as tensões que se verificaram no cerne desse reordenamento muito se devem aos intentos de parte das elites estatais de construírem um novo espaço público conexo à cidadania social e ao mundo do trabalho - o que provocou fortes resistências (Diniz e Boschi, 1991; Castro Gomes, 1988; Costa, 1999; Cardoso, 2010). O encaminhamento da legislação social dentro de uma ordem corporativa foi determinado, em grande medida, pela magnitude dessas resistências, e não por qualquer voluntarismo das elites estatais em criar uma "ideologia de Estado" sobredeterminante dos elementos da realidade.

Uma das primeiras iniciativas do regime de Vargas no campo social foi regulamentar o direito de sindicalização das classes operárias. A Lei de Sindicalização (Decreto no 19.770 de 19/03/1931) consagrou o princípio da unidade sindical, reconhecendo a primazia do sindicato profissional, definindo-o ao mesmo tempo como órgão consultivo e de colaboração com o poder público. Com o referido Decreto, as associações operárias passavam a transitar sob a órbita do Estado, inserindo-se num movimento de "oficialização de classes" para fins de titularidade a um benefício social (Moraes Filho, 1978).

Apesar de o Decreto 19.770 instituir a sindicalização como facultativa, ela se tornava, na prática, compulsória, visto que somente os sindicalizados poderiam gozar dos benefícios da legislação social. É nesse ponto controverso da legislação trabalhista e sindical que se constituirá a amarração entre os sindicatos e o seguro social. A vinculação dos benefícios do seguro à obrigatoriedade da sindicalização será a pedra de toque de toda a legislação social do Estado. Tal vinculação tornou-se um

DADOS - Revista de Ciências Sociais, Rio de Janeiro, vol. 61, n² 2, 2018 
dos principais recursos para estruturar os sindicatos no país ao passo que também ampliava a base coletiva do seguro social. Ressalte-se que o mesmo valia para os demais benefícios da legislação trabalhista, como os contratos coletivos de trabalho e as convenções coletivas, que só seriam extensivos para os sindicalizados.

O caráter compulsório (dissimulado) da filiação sindical encontrava justificativa na baixa ou quase nula sindicalização verificada entre os trabalhadores situados fora dos principais centros industriais do país. O adensamento do número de sindicalizados era uma estratégia deliberadamente perseguida pelos próprios técnicos do Ministério do Trabalho, Indústria e Comércio (MTIC). A despeito das controvérsias suscitadas em torno do Decreto 19.770, Joaquim Pimenta afirmava que este:

fora elaborado tendo-se em conta a situação real das classes trabalhadoras do Brasil; os obstáculos que se antepunham à sua organização e a uma política social que fosse a expressão de interesses que teriam de ser ritmados por um regime legal que resultasse de uma aproximação e se fizesse mediante um compromisso por parte do Estado de reconhecer no sindicato, mais do que uma simples sociedade civil, um órgão necessário ao equilíbrio da ordem jurídica na economia nacional (Pimenta, 1935: 3).

Os tratadistas brasileiros do direito do trabalho, bem como os técnicos do MTIC, desenvolveram uma aversão, não totalmente injustificada, a alguns arranjos organizativos, como a autonomia e o pluralismo sindicais, e a organização dos seguros no âmbito das empresas, em vista do que estes poderiam representar numa ordem social constituída por fortes desigualdades. Nesse sentido, reconhecia-se explicitamente que sem estratégias de indução do Estado, centradas na promoção do sindicato único e do seguro social público, compulsório e de base profissional, e apoiadas por um direito do trabalho legislado, as lutas dos trabalhadores pela conquista de novos direitos sucumbiriam às pressões patronais.

Portanto, na opinião da maioria desses tratadistas e técnicos, o que deveria sobressair na dinâmica dos conflitos sociais era a potestade do direito do trabalho (Oliveira Vianna, 1938). Segundo eles, a ação tutelar exercida pelos órgãos de regulação do trabalho seria provisória, visto que ela deixaria de existir tão logo se estabelecesse uma real paridade de reivindicações no conflito entre capital e trabalho (Segadas Viana, 1943). Também afirmavam a "íntima vinculação entre os sindicatos e o 
seguro social" e a necessidade de transformar o último em um importante recurso de ação coletiva para a organização dos primeiros (Cultura Política, no 9, 1941:293) ${ }^{7}$, pois seria através dessas duas instituições que se chegaria a um "verdadeiro equilíbrio entre os interesses associativos e materiais das classes trabalhadoras" (Freitas, 1942:153).

Antes do advento da Constituição de 1934, a legislação social vinha avançando em compasso com as diretrizes do MTIC. No período de 1931 a 1934, são promulgados vários decretos abrangendo todas as reivindicações referentes à regulamentação das condições de trabalho que nos anos anteriores haviam sido explicitadas pelo operariado brasileiro (Castro Gomes, 1988).

A Carta de 1934 consagrava o princípio, tão almejado pelos trabalhadores, da estabilidade no emprego. Conforme destacado, desde a organização dos primeiros arranjos previdenciários para os funcionários do Estado que a estabilidade era perseguida pelos trabalhadores. Mais tarde, o Decreto no 62 de 1935 veio regulamentar o artigo 121 da Constituição de 1934 que previa a extensão do instituto da estabilidade, até então restrito aos seguros sociais, para os contratos de trabalho (Santos, 1979; Werneck Vianna, 1999 [1976]). Deve-se ressaltar, no entanto, que o patronato questionou o referido Decreto, alegando que o estatuto da estabilidade, além de ferir a "necessária" mobilidade da força de trabalho, incitava a indisciplina no interior das empresas (idem, 1999[1976]). O que preocupava o patronato agora, diferentemente da década de 1920, era as consequências da adoção do instituto da estabilidade sob a nova ambiência institucional produzida pelo Estado corporativo na década de 1930. Ainda que esse Estado guardasse intimamente os interesses empresariais, aos olhos do patronato ele se afigurava como uma incógnita; um Estado que passava cada vez mais a ser premido tanto pelas exigências do processo acumulativo quanto pelas tensões provocadas pelo crescimento do seu ativismo na regulamentação das condições de trabalho.

Contudo, a criação dos Institutos de Aposentadorias e Pensões (IAPs), a partir de 1933, vem ao mesmo tempo modificar a relação dos trabalhadores com o seguro social e com as empresas. ${ }^{8} \mathrm{O}$ propósito do governo em criar esses Institutos adquiria grande envergadura. Ao estender o campo de abrangência do seguro para as categorias profissionais, o mundo operário passou a perceber que seu próprio modo de organização, dentro da nova ordem corporativa que então se 
estruturava, não podia senão colidir com as velhas concepções privadas e paternalistas de proteção centradas nas empresas.

Com os IAPs, o trabalhador poderia no mínimo barganhar sua mobilidade no mercado de trabalho. Ele não mais dependeria de uma única empresa para obter seus benefícios previdenciários, e sim da inscrição em uma categoria; em um estatuto profissional. Isso proporcionava uma mobilidade regulada para a força de trabalho que, estando acima do arbítrio da empresa, passava a depender do poder de negociação dos sindicatos profissionais. As elites estatais brasileiras concebiam que os benefícios materiais oferecidos pelos IAPs à classe trabalhadora, além de adquirirem maior visibilidade por se estenderem a toda uma categoria, e desta para as demais, poderiam conferir maior atratividade à sindicalização profissional.

O progressivo adensamento dos seguros sociais com a criação dos IAPs não entrava apenas em sintonia com o movimento de sindicalização das diversas categorias, mas com as novas diretrizes administrativas do governo na gestão do social. Através dessas diretrizes, buscava-se racionalizar as bases atuariais de organização do seguro, visando o emprego de suas reservas técnicas em diversas atividades econômicas e sociais.

O seguro social no Brasil, apesar de iniciado em 1923, não dispunha de nenhum serviço de organização atuarial. Somente no início da década de 1930 que é criado o cargo de atuário no MTIC (Louzada, 1990 [1933]). Nessa época, havia um total desconhecimento da função do atuário e dos princípios que norteavam tal profissão. A atuária era tratada como uma mera técnica contábil de controle de custos. Foi contra essa ideia que tiveram de lutar os primeiros atuários nomeados pelo MTIC para se firmar enquanto profissionais do campo previdenciário, ou seja, enquanto profissionais das técnicas de securitização dos riscos sociais (Cultura Política, no 21, 1942).

A centralidade dos problemas atuariais no âmbito do seguro devia-se à maior necessidade de racionalização administrativa dos IAPs frente à gradual expansão do número de segurados. Saliente-se ainda o fato de essa necessidade surgir concomitantemente aos esforços do governo em adotar critérios de racionalidade para o funcionamento de todo o aparato burocrático do Estado. É do próprio ensaio de organização administrativa realizado por uma instituição previdenciária, o Instituto de Aposentadoria e Pensões dos Industriários (IAPI), que surgirá o pa- 
drão burocrático a ser seguido pelos órgãos administrativos do Estado brasileiro (Hochman, 1992). ${ }^{9}$

É importante ressaltar que o MTIC e o IAPI eram majoritariamente dirigidos por técnicos que, acima de tudo, deveriam cumprir com zelo os objetivos do regime varguista no campo social, qual seja: o de incorporar gradualmente o proletariado nacional nas políticas sociais do Estado. Assim, através dessas duas instituições, tentava-se conferir um novo tratamento para a administração do Estado social brasileiro, tendo como princípio motriz o engajamento dos seus servidores na coisa pública. No entanto, esse engajamento deveria se tornar conexo às necessidades do mundo do trabalho; uma tarefa nada fácil de ser realizada, visto que a organização racional do aparato previdenciário, excessivamente valorizada por esses servidores, colidia diretamente com a ordem corporativa na qual se inseriam os sindicatos.

Grande parte dos profissionais vinculados à burocracia previdenciária cultivava uma imagem da previdência social como uma instância que deveria ser gerida exclusivamente por um saber técnico, o qual deveria antecipar-se às pressões que poderiam ameaçar os objetivos da política social varguista. Esse agir por antecipação, endossado por esses profissionais, partia de dois diagnósticos. O primeiro dizia respeito aos interesses privados que se opunham à publicização do seguro social, representados pelo patronato e pelas seguradoras privadas que operavam no ramo dos seguros médicos e de acidentes de trabalho. $\mathrm{O}$ segundo, mais controverso, referia-se à "incapacidade" de os sindicatos realizarem as tarefas administrativas necessárias à integração do trabalhador nacional nas políticas sociais do Estado. A missão desses profissionais como intelligentsia, por mais controversa, consistia, portanto, em dar efetividade a um projeto ambicioso que visava "criar uma burocracia profissional" e ao mesmo tempo articulá-la ao mundo do trabalho. É desnecessário dizer que a burocracia previdenciária desenvolveu uma atitude ciosa em relação às pressões do sindicalismo sobre o controle dos fundos do seguro social. Essa intelligentsia, a mesma que durante as décadas de 1930 e 1940 criará a Justiça do Trabalho, o Imposto Sindical e a Consolidação das Leis do Trabalho (CLT), temia pelo destino dos fundos previdenciários se esses, porventura, caíssem nas mãos dos sindicatos. ${ }^{10}$

Apesar dessas tensões, a burocracia deteve uma relativa influência sobre a organização dos IAPs durante as décadas de 30 e 40 . O patronato

DADOS - Revista de Ciências Sociais, Rio de Janeiro, vol. 61, nº 2, 2018 
e as seguradoras privadas, por sua vez, trataram de explorar os nichos da assistência médica e do seguro de acidentes de trabalho. É importante destacar que o Estado brasileiro demonstrou certa incapacidade de impor suas decisões sobre esses setores. Nesse aspecto, cabe frisar que a primeira lei social brasileira, a Lei de Acidentes do Trabalho (Decreto-Lei no 3.724 de 15/01/1919), demonstrou ser vulnerável à força persuasiva do patronato para fazer valer os interesses privados no campo do seguro. Ademais, uma lei de acidentes de trabalho que se institui sem a devida regulamentação das condições de trabalho tornar-se-ia um campo fértil para se criar todo o tipo de fatura sobre os riscos dos acidentados (Castro, 1935; Abranches, 1974). Não é por acaso que as seguradoras privadas viam no dispositivo indenizatório criado pelo seguro de acidentes um "nicho de mercado", criando, assim, um "mercado dos riscos profissionais". Daí surgiria, por assim dizer, o primeiro parasita das deficiências estruturais que presidiram o nascimento do Estado social no Brasil. ${ }^{11}$

A expansão dos seguros sociais para novas categorias de trabalhadores também requeria que se dotasse o sistema previdenciário de maior uniformidade, o que colocava na ordem do dia a necessidade de fusão das Caixas pelos Institutos, e destes por uma única instituição nacional de previdência. Contudo, deve-se salientar que essa expansão abonou as empresas dos seus encargos com o sistema previdenciário. Os legisladores esperavam que a poupança coletiva da classe trabalhadora se constituísse não só a partir do crescimento da massa salarial, mas do lucro líquido das empresas. Entretanto, a contribuição do empregador permaneceu proporcional à contribuição do empregado. Isso significava que a contribuição patronal tornava-se função da massa salarial paga pela empresa e não de seu faturamento, desonerando assim o capital dos encargos previdenciários vis-à-vis o trabalho (Santos, 1979:26).

Apesar desses problemas, a questão do associativismo do trabalhador brasileiro nunca deixou de ser uma preocupação central das políticas de previdência social durante o governo Vargas. E é nesse aspecto que reside sua importância como recurso de ação coletiva para o proletariado nacional. Se, por um lado, o Estado mostrava-se incapaz de controlar certas áreas do seguro, por outro, promoveu medidas de grande impacto para a classe trabalhadora, tais como a construção de conjuntos habitacionais e a criação de alguns serviços no campo da assistência, como o Serviço de Alimentação da Previdência Social (SAPS). 
O SAPS foi uma autarquia instituída em 1940 (Decreto-Lei no 2.478), subordinada diretamente ao MTIC. Sua proposta original era promover a melhoria das condições nutricionais da classe trabalhadora, através da criação de restaurantes populares (Castro Gomes, 1999). Contudo, para além desse objetivo, foram agregadas ao espaço dos restaurantes populares atividades de lazer e cultura que tornaram os benefícios da sindicalização e da filiação compulsória ao seguro social mais visíveis e atrativos para os trabalhadores.

Saliente-se que a política habitacional do governo Vargas foi edificada sobre as instituições do seguro social. Visando solucionar o problema do déficit habitacional das famílias da classe trabalhadora, o governo determinou que fossem empregados até $50 \%$ das reservas técnicas das instituições previdenciárias na construção de moradias. ${ }^{12} \mathrm{O}$ problema da má utilização das reservas acumuladas pelos IAPs causava vários inconvenientes para o governo. Um desses inconvenientes concernia à concentração dessas reservas em investimentos que incitavam a especulação no mercado imobiliário das grandes cidades. Isso, em contrapartida, provocava o encarecimento dos aluguéis e dos materiais de construção, comprometendo o minguado orçamento dos setores populares urbanos. Aliás, esta era uma das principais justificativas para a intervenção do Estado nas operações de crédito efetuadas pelos Institutos:

O custo elevado das construções e a rendosa amortização dos capitais privados invertidos em operações imobiliárias impossibilitam às massas proletárias uma habitação adequada. Uma parte importante dos salários é absorvida pela alta dos aluguéis. Sendo, com raras exceções, o capital privado incapaz de prover, em nível compatível com os juros esperados, às necessidades de habitação dos trabalhadores, tornou-se imprescindivel uma intervenção do Estado (Cultura Política, no 33, 1943: 75).

A política de financiamento da habitação no âmbito do seguro social também era vista pelo governo como parte integrante de uma política mais geral de "promoção do trabalhador nacional" (Cultura Política, no 46, 1944a: 12). Vale registrar que os conjuntos habitacionais construídos com os recursos dos Institutos muitas vezes levavam os nomes de alguns próceres do regime varguista, demonstrando, nesse aspecto, como os benefícios do seguro estavam associados ao imaginário construído em torno do regime:

DADOS - Revista de Ciências Sociais, Rio de Janeiro, vol. 61, n’ 2, 2018 
O IAPETEC mantém em pleno funcionamento duas carteiras independentes a imobiliária e a patrimonial, que já prestaram assinalados serviços. Foi assim construída a Vila Waldemar Falcão, na Ilha do Governador, com oitenta casas, divididas em três tipos diferentes: E, F-1 e F. Esses tipos de casas têm as mesmas acomodações (sala de jantar, dois quartos, banheiro, cozinha, tanque e quintal). Outra vila construída é a chamada Agamenom Magalhães, em Recife, com setenta casas, as quais têm, além das acomodações antes especificadas, serviço de assistência médica e hospitalar para os seus moradores, grupo escolar, playground, mercado, etc. (Cultura Política, no 9, 1941:228).

No Rio Grande do Sul, como era de se esperar, havia a "Vila Getúlio Vargas", com setenta e cinco prédios isolados, "todos com mobiliário confortável e de magnífico aspecto" (idem:229). A ampliação dos benefícios do seguro social para as categorias profissionais, apesar de insuficiente e restrita aos trabalhadores urbanos, dilatou o universo previdenciário. Prova disso é que num curto lapso de tempo, de 1935 a 1944, o número de contribuintes para os IAPs, e, por consequência, de sindicalizados, mais que quintuplicou, passando de 400 mil para 2.2 milhões de segurados ativos (Cultura Política, nno 46, 1944a: 13). A magnitude dos recursos envolvidos em cada um dos IAPs não era nada desprezível. Devido à baixa quantidade de benefícios em estoque e à alta arrecadação de contribuições, os capitais dos Institutos passaram a ser investidos na chamada "batalha da produção" do início dos anos 40, destinando-se a iniciativas que visavam fortalecer o capitalismo nacional, como o financiamento à Carteira de Crédito Industrial e Agrícola do Banco do Brasil, à subscrição de parte do capital do Instituto de Resseguros do Brasil e da Companhia Siderúrgica Nacional (CSN).

Em suma, a criação dos IAPs, além de promover a ampliação da base sindical por intermédio dos seus benefícios, vai transformar a previdência social brasileira em um importante instrumento de poupança coletiva. O capitalismo brasileiro fincava raízes nas instituições do mundo do trabalho, dando sinais de que sua vitalidade dependeria do crescimento da massa salarial na economia e do adensamento dos sindicatos e do universo previdenciário. Também aqui a política previdenciária se encontraria numa encruzilhada: seja como expressão de uma "propriedade coletiva" destinada à formação do patrimônio da classe operária, ou como estímulo à acumulação capitalista orientada pelo Estado. 


\section{O ESTADO NOVO, O SEGURO SOCIAL E AS INSTITUIÇÕES DE REGULAÇÃO DO TRABALHO}

É sabido que a suspensão dos direitos políticos durante a vigência do Estado Novo (1937-1945) colocou as associações sindicais, bem como suas lideranças mais combativas, sob forte intervenção e vigilância do Estado. Para sacramentar esse processo, uma nova Constituição, de nítida feição autoritária, é outorgada em 1937. Esta manteve toda legislação social até então produzida, exceto o direito à greve, que se tornaria ilegal.

Contudo, é durante este conturbado e controverso período da história política brasileira que a legislação social adquire corpo. Nele, materializam-se os principais órgãos responsáveis por implementar a política social e trabalhista do governo Vargas. Portanto, afastados os antagonistas do regime, especialmente as "ameaças do comunismo", e protegido os interesses do empresariado nacional, a burocracia estadonovista empenhar-se-ia em implementar seu projeto de adensar coletivamente os sindicatos e ampliar o universo do seguro social, mediante fortalecimento das instituições de regulação do trabalho.

Deve-se ressaltar que, mesmo acuada, a classe operária brasileira não permaneceu "destituída de consciência social" sendo "manipulada" pelo governo (Castro Gomes, 1988; Ferreira, 1997). Tal como salienta Alessandro Pizzorno (1967), a consciência política dos atores sociais não se encontra prefigurada em qualquer ideologia e pode não ser anterior à sua ação política (Pizzorno, 1967). Nesse sentido, os trabalhadores brasileiros viram na própria mudança legislativa e legal que o Estado varguista promovia no campo dos direitos sociais uma oportunidade para realizar suas aspirações relativas à proteção social. ${ }^{13}$

É nesse período que a Justiça do Trabalho é regulamentada (Decreto-Lei no 1.237, de 02/03/1939). A partir de 1941, o Conselho Nacional do Trabalho (CNT) assumiria um importante papel. Este, além de ser o órgão mais importante da Justiça do Trabalho, tornou-se a instituição de orientação dos recursos arrecadados pelas instituições de previdência. Como órgãos do Ministério Público, funcionavam ainda, junto ao CNT, a Procuradoria da Justiça do Trabalho e a Procuradoria de Previdência Social. OCNT se instituía como uma espécie de "Ministério Plenipotenciário", híbrido e de duas cabeças, acumulando funções de justiça e de administração, englobando todas as questões que envolviam o trabalho e a previdência social (Cultura Política, no 46, 1944a: 20). 
Em 1939, é promulgada uma nova lei de sindicalização (Decreto-lei no 1402), estabelecendo oficialmente a unidade sindical e a tutela dos sindicatos ao MTIC (os sindicatos não reconhecidos pelo Estado foram dissolvidos). Finalmente, no dia 1 de maio de 1940, é regulamentado o salário mínimo (Decreto no 2.162 de 01/05/1940). Este, no entanto, seria fixado em valores nominais bastante inferiores ao custo de vida das principais cidades brasileiras, variando para baixo, conforme se calculava o custo médio de vida nas diferentes regiões do país.

Apesar da estrutura portentosa do MTIC, o Estado contava com parcos recursos para fiscalizar a vigência do salário mínimo em todo o território nacional, em face da relutância do patronato em aceitá-lo, mesmo sendo fixado como um salário de subsistência (Cardoso, 2010:233). Porém, o seu valor arbitrado tornar-se-ia importante referência para a fixação das expectativas em torno de uma renda que passava a ser assegurada e convertida em direito, especialmente para os trabalhadores que recebiam as piores remunerações, incluindo a massa de trabalhadores rurais (idem, 2010). Além disso, o valor do salário mínimo também indexaria o valor dos benefícios do sistema previdenciário. Esse fato era tão mais importante na medida em que o principal problema dos baixos valores das aposentadorias pagas pelos Institutos devia-se à situação precária dos salários e à sua falta de uniformidade. Aliás, esta era uma das principais preocupações que afligiam os técnicos do MTIC. Djacir Menezes, membro do CNT, questionava em tom premonitório: "O problema dos Institutos decorre do precário poder aquisitivo das massas laboriosas. Como organizar um sistema de proteção eficiente com salários de débil poder aquisitivo?" (Menezes, 1943:337).

Ainda em 1940, é criado o Imposto Sindical (Decreto-lei no 2.387), que obrigava todos os trabalhadores - sindicalizados ou não - a destinar uma contribuição referente a um dia de trabalho para a organização dos seus sindicatos. A instituição do imposto sindical, dentre outras finalidades, vinha auxiliar os sindicatos a assistir seus associados nos processos de concessão de benefícios junto às instituições previdenciárias. Em 1942, é criada a Comissão do Imposto Sindical (CIS) (Decreto-lei no 4.298), visando racionalizar o emprego dos recursos provenientes da contribuição sindical compulsória. Em 1943, surge a Comissão Técnica de Orientação Sindical (CTOS) (Decreto nํ⒌199, de 16/01/1943), como medida oficial para incrementar o número de sindicalizados no país. ${ }^{14}$ 
No dia 1 de maio de 1943, é promulgada a Consolidação das Leis do Trabalho (CLT) (Decreto-Lei № 5.452, de 01/05/1943), ordenando todas as leis do trabalho até então existentes. A CLT vinha finalmente consagrar o instituto da estabilidade do trabalhador no emprego ao inscrever em seu artigo 492 que: "O empregado que contar mais de dez anos de serviço na mesma empresa, não poderá ser despedido senão por motivo de falta grave ou circunstância de força maior devidamente comprovada" (BRASIL, 1943). Cumprido, portanto, o prazo de dez anos, o trabalhador tornava-se estável e não poderia ser despedido, mesmo na hipótese de falta grave. É nesse ponto da legislação social e trabalhista que o dispositivo da estabilidade termina por desvincular-se de suas raízes atuariais, tal como consagrada pela legislação das CAPs, para se transformar em um importante instrumento de estabilização das expectativas do trabalhador quanto à sua permanência no emprego (Santos, 1979).

O instituto da estabilidade foi, sem dúvida, uma das maiores inovações do direito social brasileiro. Através dele, o legislador declarava sua intenção de limitar o poder do mercado na contratação de mão de obra, transformando o trabalhador num "proprietário" do seu emprego (Werneck Vianna, 1999 [1976]:339). A finalidade aqui era fixar o trabalhador em uma "comunidade extrapatrimonial de trabalho" (Supiot, 1994), assentada em regras jurídicas. ${ }^{15}$

Em compasso com a CLT, e como último desenlace das políticas previdenciárias do período, também era anunciada a Lei Orgânica da Previdência Social, em 1944, procurando dar uniformidade aos IAPs e acompanhar a tendência verificada a partir dos anos 1940 de crescimento da massa salarial na economia.

Enfim, com a CLT a regulação dos conflitos entre capital e trabalho passava a ser arbitrada, tal como idealizada por seus formuladores. Os sindicatos profissionais, o seguro social e a Justiça do Trabalho seriam os pilares de sustentação do edifício da proteção do trabalho - proteção associativa, material e jurídica. Esses três elementos estavam estritamente vinculados, embora o que cimentava as relações entre eles era o controle da atividade sindical pelo Estado.

A estratégia perseguida pelos legisladores sociais das décadas de 1930 e 1940 trazia consigo a promessa de construção de uma "sociedade salarial" centrada no eixo trabalho e proteção securitária. Tal promessa advinha das vantagens da sindicalização compulsória, associada, antes 
de tudo, ao acesso aos benefícios do seguro social. Por meio de induções burocráticas e legais, a securitização da força de trabalho levava ou "forçava" sua sindicalização. Esta, por seu turno, poderia fortalecer os vínculos entre os benefícios do seguro e a valorização do salário mínimo, uma vez que se contava com a expectativa de que as categorias mais mobilizadas puxariam para cima os salários das categorias menos mobilizadas. Ao lado disso, o sistema de garantias jurídicas relacionadas ao trabalho se mantinha em função do instituto da estabilidade.

Os problemas aqui surgiam dos controles privados de alguns componentes do seguro, indispensáveis à ação coletiva dos trabalhadores, e ainda, da questão de como incluir nesse mecanismo promissor o imenso contingente da população que permanecia sem proteção: os trabalhadores rurais, os domésticos, os desempregados; em suma, a esmagadora maioria da população brasileira.

\section{O SEGURO SOCIAL E O VATICÍNIO DE OLIVEIRA VIANNA}

Oliveira Vianna ${ }^{16}$ foi um dos poucos intelectuais do período a perceber o caráter coletivo da "propriedade da previdência" e a modificação de atitudes que ela provocaria ao disseminar nos trabalhadores um sentimento de pertencimento a uma coletividade. Ao contrário dos que viam no seguro social um instrumento apenas compensatório ao esforço produtivo dos trabalhadores, o sociólogo fluminense dizia que o principal papel dos IAPs seria o de "organizar a capilaridade social da classe trabalhadora", preparando-a para assumir um papel de destaque na vida pública (Oliveira Vianna, 1951:50).

Em Oliveira Vianna, a organização da previdência social remetia diretamente para a questão da "presença do povo" no Estado. Daí a importância de se organizar o regime corporativo na sociedade brasileira tendo por base os seguros sociais coletivos e os sindicatos profissionais, pois seriam através desses instrumentos que se diminuiriam as assimetrias de poder entre patrões e empregados.

Em razão da promessa das instituições previdenciárias do país, chamadas por ele acertadamente de "instituições de propriedade social", de equacionar a crônica escassez de recursos da economia brasileira, a eficiência das mesmas apenas se provaria no futuro, quando fosse possível unir a densidade organizativa da força de trabalho com a densidade das suas poupanças coletivas. Tais instituições criariam as condi- 
ções propícias ao florescimento do capitalismo brasileiro: um capitalismo vocacionado a estruturar as solidariedades do mundo do trabalho.

Oliveira Vianna preconizava que os fundos previdenciários organizados coletivamente, longe de serem simples recursos para o "bem-estar" material, produziriam profundos impactos multiplicadores na vida pública e associativa da nação. Eles não apenas assegurariam os "confortos do lar" e as garantias contra as vicissitudes da vida, mas fariam brotar as "escolas, os recreios, e os clubes operários", constituindo-se em "grandezas associativas" que poriam um fim no baixo estima do trabalhador nacional (idem:127).

Em referência ao Imposto Sindical, Oliveira Vianna prenunciava os potenciais efeitos que a instituição desse "tributo" produziria para o associativismo operário brasileiro ao enfatizar a vinculação entre a sindicalização compulsória e o seguro social.

Esta previsão é tanto mais fundada quanto, até agora, as nossas associações de previdência têm operado sozinhas e isoladas. Mas, porventura, já imaginaram o que elas poderão dar aos nossos trabalhadores em benefícios com uma futura articulação, que necessariamente há de vir, dos seus serviços a serem organizados - uns obrigatórios, outros facultativos - das associações sindicais, quando começarem a manejar e aplicar as reservas patrimoniais provindas do nosso tributo sindical recentemente instituído? Tudo isso, sem dúvida, abre ao nosso operariado uma perspectiva de grandeza incomparável (idem: 29).

Enfim, no seu projeto de nação o seguro social seria a expressão de uma nova ordem fundada no direito do trabalho, na cultura do associativismo e no espírito de solidariedade. Havia por parte de Oliveira Vianna uma expectativa otimista de que o arcabouço da legislação social instaurado pelo governo Vargas pudesse enfim dissolver os resquícios herdados do liberalismo oligárquico. Mas esse otimismo não o eximia de apontar, consternadamente, as imperfeições dessa mesma legislação:

O problema social no Brasil, com efeito, não foi, nem pode ser ainda, considerado na universalidade dos seus aspectos, nem a solução que lhe foi dada na obra legislativa da Revolução é uma solução integral. Neste dominio estamos, por assim dizer, ainda encerrados dentro do perímetro das cidades. O mundo rural brasileiro continua intacto, fora da ação tutelar e renovadora desta nova política social. Não enfrentamos ainda os problemas sociais que o nosso interior com sua numerosa população proletária encerra (idem: 16).

DADOS - Revista de Ciências Sociais, Rio de Janeiro, vol. 61, nº 2, 2018 
Aliás, esse problema apontado por Oliveira Vianna será o Calcanhar de Aquiles da legislação social brasileira; um problema que, a bem dizer, somente será parcialmente equacionado, anos mais tarde, com a extensão dos seguros sociais para os trabalhadores rurais na década de $1970 . .^{17}$

Enquanto a política social orientou-se no sentido de criar no mundo urbano uma nova forma de "propriedade coletiva" (o seguro social), a estrutura da propriedade no mundo rural permaneceu intocada. Havia por parte dos legisladores brasileiros uma preocupação em reparar as injustiças históricas cometidas contra o campesinato. Mas o campo se mostrava uma fronteira impenetrável à legislação social.

No Brasil, o tema da extensão dos benefícios sociais para os trabalhadores rurais assumia uma destacada importância. ${ }^{18}$ Além disso, a extensão da legislação social ao campo afigurava-se fundamental para conferir legitimidade ao discurso da política social estadonovista. Reconhecia-se que o primeiro passo a ser dado nessa direção consistia em estender os direitos de sindicalização para o trabalhador rural. Na opinião de alguns técnicos do MTIC, a concessão da legislação social para os trabalhadores rurais deveria vir atrelada à obrigatoriedade da sindicalização, pois "se era assim com os operários porque haveria de ser diferente com as populações rurais, até então marginalizadas da legislação" (Pinho, 1941:25). ${ }^{19}$

Tal extensão, contudo, implicava em persuadir as elites agrárias que, além de cimentarem politicamente as forças que sustentavam o regime varguista, eram os protagonistas do projeto de transformação do campo pela via da penetração do capitalismo agrário voltado a dinamizar a economia agroexportadora brasileira (Werneck Vianna, 1999 [1976]).

Virgínio Santa Rosa, um observador perspicaz dos acontecimentos que sucederam à Revolução de 30, captou bem o sentido lento que se imprimiria ao movimento então em curso. Segundo Santa Rosa (1976 [1933]), o peso dos latifúndios e das massas rurais isoladas impediria, de pronto, qualquer tentativa de aprofundar as medidas de reforma social, pois, nas suas palavras: "a inércia da nacionalidade intervinha em prejuízo da celeridade de execução da obra planejada" (Santa Rosa, 1976 [1933]:124). A partir daí, portanto, não havia o que escolher, e a legislação social destinada aos segmentos urbanos resultava na única oportunidade para o governo da Revolução transformar a sociedade brasileira. 
Não obstante esses impedimentos, o caráter limitado da cidadania social no país trazia as possibilidades do seu próprio alargamento cívico, ao criar nos grupos não incluídos as expectativas de serem inscritos no conjunto de proteções que o Estado havia instituído em torno do trabalho urbano. Em vista das resistências colocadas pelo patronato agrário e industrial, a legislação social teria de ser construída com toda a voluptuosidade de artifícios. Assim, construiu-se um “horizonte de possibilidades" em torno dos direitos de proteção do trabalho e da política social para o mundo urbano, que, mesmo limitado, criou nos setores populares, pela primeira vez, um limiar de sensibilidade social para a percepção dos seus direitos recém-instituídos (Cardoso, 2010). ${ }^{20}$

A forma pela qual os direitos sociais foram implementados no país tem a ver com as intricadas relações apontadas acima. Para dar vigência a um sistema de direitos sociais assentados sobre uma ordem social profundamente desigual, o Estado brasileiro munira-se de um poderoso artifício, criando um sistema de "tensões reguladas" em torno da concessão desses direitos. É a partir desse sistema que se estrutura o arranjo corporativo das políticas sociais, no qual o seguro social público e compulsório e a sindicalização una e profissional surgem fortemente imbricados. Também é sob sua influência que o direito do trabalho no país assume um caráter legislado. E é com ele, finalmente, que se implementam os direitos sociais dentro de uma ordem política autoritária.

A expressão desse processo foi definida por Santos (1979), através do conceito de "cidadania regulada" - conceito este que por sua generalidade pode ser ampliado para abarcar todas as situações históricas nas quais os direitos sociais surgiram vinculados à noção de ocupação. ${ }^{21} \mathrm{O}$ conceito em si mesmo não traz nenhuma novidade, visto que a maioria dos países que organizaram arranjos públicos e estatutários de proteção seguiu critérios ocupacionais na concessão desses direitos (Titmuss, 1963; Esping-Andersen, 1990). Além do mais, ressalte-se o fato de as tensões "cívicas" (participação no processo político) e "domésticas" (corporativização dos interesses) serem inerentes à própria constituição da cidadania (Boltanski e Thévenot, 2006); uma tensão que envolve a difícil convivência "igualitária" e "solidária" dos agentes sociais para a afirmação autônoma de objetivos e interesses de qualquer natureza (Reis, 2000).

Mas o que Santos (1979) quer chamar a atenção é para o modo peculiar pelo qual as elites estatais brasileiras se apoderaram desse artifício

DADOS - Revista de Ciências Sociais, Rio de Janeiro, vol. 61, nº 2, 2018 
para criar as condições de institucionalização dos programas do Estado social no país. A "cidadania regulada" seria, portanto, mais um dos tantos artifícios que essas elites empregaram, desde a independência, para resolver os problemas da constituição da ordem numa sociedade organizacionalmente rarefeita, quer seja essa ordem liberal, num período, ou "socialdemocrata", em outro. Assim os artifícios empregados, num ou noutro caso, serviriam para solucionar o problema de uma ordem liberal sem liberais, sem "livre iniciativa", e de uma ordem "socialdemocrata" sem vertebração social, sem poder sindical. Daí o particular modo de operação dessa "cidadania regulada" na realidade brasileira, criando, "pelo alto", as condições para a emergência dos direitos sociais, e regulando paulatina e categoricamente os grupos credenciados a participar do universo desses direitos.

Ao contrário dos países nos quais os direitos de proteção nasceram associados à maior densidade social dos sindicatos, a ausência dessa densidade, no Brasil, fez com que o direito do trabalho e os seguros sociais desempenhassem os papéis ativadores de uma "luta de classes institucionalizada no capitalismo" (Korpi, 1983), ${ }^{22}$ organizando lentamente as forças estruturantes do mundo do trabalho. Esse sistema de tensões reguladas era particularmente eficaz para os trabalhadores com poucos recursos organizativos.

O mecanismo compulsório de filiação ao seguro social de base profissional e o imposto sindical, ambos criados durante o primeiro governo Vargas, acabaram se convertendo em importantes instrumentos que auxiliaram o processo de sindicalização da classe trabalhadora brasileira, transformando os benefícios da legislação social em importantes recursos de ação coletiva. Os benefícios do seguro social tornavam a sindicalização mais atrativa, e esta, por seu turno, fortalecia as instituições do seguro ao serem constituídas por grupos mobilizados em torno da ampliação dos direitos sociais. Prevaleceu aqui uma estratégia de indução estatal orientada a estender os benefícios da legislação social para setores da classe trabalhadora urbana que, se desprovidos desses recursos, e dadas as características do patronato brasileiro - um patronato extremamente hostil aos direitos dos trabalhadores-, permaneceriam sem qualquer proteção.

Essa estratégia de indução teve importantes consequências, sobretudo para segmentos da população, cujos problemas, na época, não adquiriam "consistência sociológica imediata", isto é, não possuíam visibili- 
dade (Rosanvallon, 2008). E tais consequências não foram nada desprezíveis, considerando que os efeitos da legislação social foram salientes, especialmente para um proletariado quase todo ele proveniente do mundo rural e acostumado a viver sob severas privações.

Conforme salientado por diversos autores, após a promulgação da legislação social nas décadas de 1930 e 1940, o êxodo do campo para as cidades se intensificou, devido à "atratividade" do trabalho registrado (trabalho com carteira assinada) e dos direitos sociais que nele vinham embutidos, então concedidos exclusivamente para o mundo urbano (Lopes, 1964; Durhan, 1973; Cardoso, 2010).

Essa atratividade é comprovada já nos anos finais do Estado Novo. Em uma entrevista para a revista Cultura Política, em 1944, um operário (recém-chegado do campo) era inquirido sobre os motivos que o levaram a migrar para a Capital da República. O entrevistado emblematicamente respondeu que migrou para a Capital porque estava à procura de trabalho registrado e protegido (inexistente no meio rural). E que também havia tomado ciência de um discurso proferido por Vargas, no dia 1 de maio, em São Paulo, no qual o "Presidente falou-nos da nova lei de providência que está em elaboração", a qual prometia "permanência no emprego, restaurantes populares, escolas de trabalho, moradias, tudo estaria enfeixado na futura lei de beneficência" (Cultura Política, no 46, 1944b: 72).

Contudo, as décadas posteriores à montagem do arcabouço da legislação social provariam que a "promessa dos direitos" se frustraria para a maioria dos trabalhadores brasileiros. O desfrute dos benefícios do seguro social requeria que esses trabalhadores estivessem colocados em posições estáveis no mercado de trabalho. E, para desalento de muitos, o que se verificou, na prática, foi uma crescente "mercantilização do trabalho", com a consequente predominância de intensa rotatividade no emprego e de ocupações de baixa qualificação (Cardoso, 2010; Guimarães, 2015). ${ }^{23}$

Embora tal promessa não tenha se realizado por completo, a busca pura e simples da sobrevivência pela via do mercado por parte dos trabalhadores fora minimamente atenuada pelo efeito da legislação social, especialmente da legislação do seguro. Esta, conforme visto, estruturou-se, desde o seu início, como uma construção normativa, ainda que assimilada por uma massa de trabalhadores sempre à procura de trabalho e proteção social.

DADOS - Revista de Ciências Sociais, Rio de Janeiro, vol. 61, n’ 2, 2018 


\section{CONCLUSÃO}

A atividade do seguro não consiste em constatar a existência dos riscos para convertê-los numa fonte de possibilidades para o sucesso individual, como hoje parece se suceder com a proliferação dos seguros privados individuais e ocupacionais. Hoje, os particularismos socioprofissionais parecem ter ressuscitado a velha tradição mutualista no campo do seguro, mantendo um sistema que segue sendo segmentado, mas que agora se torna mais heterônomo aos "requerimentos do mercado".

Este artigo salientou que o seguro social adquiriu um destacado papel, guardando um profundo significado político e associativo, constituindo-se ainda como expressão de um vínculo que testemunhou o surgimento de uma forma específica de solidariedade. Numa sociedade como a brasileira, organizacionalmente rarefeita e marcada por forte contestação dos instrumentos públicos de regulação do trabalho, a legislação previdenciária do Estado, produzida entre as décadas de 1930 e 1940, mostrou-se bastante eficaz como instrumento de valorização associativa do trabalho. A estratégia de fortalecimento da identidade do trabalho atrelada aos benefícios do seguro social, por mais contraditório que tenha sido o seu resultado para a produção da "equidade", e num contexto no qual a "norma salarial" jamais se universalizou, ao menos manteve atrativo para os trabalhadores os seus prospectos de integração no assalariamento formal.

Essa atratividade se tornou tão mais pronunciada quanto mais precárias eram as relações de trabalho estabelecidas fora do universo da regulação estatal. Assim, o tipo de proteção que a legislação do seguro procurava institucionalizar, mediante estratégias de indução, oferecia-se como um alento para o trabalhador nacional acostumado às precárias formas de trabalho que vigiam tanto no intocado mundo rural quanto no pouco estruturado mercado de trabalho urbano.

Se, por um lado, a expansão do assalariamento formal com proteção foi constrangida, devido à forte oposição do patronato agrário e industrial, por outro, ela se destacou por ter consagrado uma regulação do trabalho que impôs certos limites ao comportamento predatório dos empregadores, construindo os rudimentos simbólicos e materiais da proteção do trabalho no país. 
E não é nada casual o fato de a amarração institucional entre seguro social e regulação pública do trabalho no Brasil permanecer intacta até os dias de hoje. Pois, para a grande maioria dos trabalhadores brasileiros, possuir um trabalho registrado ainda significa ter um emprego protegido pela Justiça do Trabalho e pelo seguro social. Significa, portanto, a garantia do acesso dos trabalhadores à justiça nos litígios contra um patronato sempre arredio em cumprir as normativas trabalhistas, e o acesso definitivo à renda, em que esses trabalhadores, após passarem por inúmeras e duras provações no mercado de trabalho, conquistam, enfim, o tão sonhado direito de se aposentar.

Pode-se apontar, como comentário final, que a legislação social varguista, mesmo criada num período de suspensão dos direitos políticos, incorporou o repertório de lutas da classe trabalhadora brasileira. E ao converter as instituições de proteção, notadamente o seguro social, em importantes recursos de ação coletiva para os trabalhadores, essa mesma legislação transformou essas lutas em efetivas conquistas. Cabe ainda salientar que as estratégias de indução institucional que possibilitaram a implementação da legislação social e trabalhista eram sociologicamente informadas, pois defrontadas com a difícil tarefa de inaugurar um processo de juridificação de direitos sociais em uma sociedade oligárquica, desigual e reticente à redistribuição. Aliás, nunca é demais lembrar que é a permanência desse fato que testemunha a durabilidade dessa legislação no tempo.

Submetido em 01 de outubro de 2015 Reapresentado em 07 de maio de 2018 Aprovado em 13 de julho de 2018 


\section{NOTAS}

1. Estimar riscos, calcular contribuições, registrar casos de danos sofridos e determinar benefícios, tudo isso requeria que o Estado, através de suas técnicas securitárias, conferisse maior legibilidade ao social, aproximando-se dos conflitos reais existentes na sociedade. Paradoxalmente, o conhecimento técnico e atuarial para cumprir tais funções, por parte dos agentes do Estado, também requeria certa "distância profissional" em relação a esses conflitos (Swann, 1988).

2. Diversos autores ressaltaram as diferenças na formação do proletariado do Rio de Janeiro e de São Paulo durante a Primeira República, destacando também o caráter específico de suas associações (Castro Gomes, 1979, 1988; Carvalho, 1985; Pinheiro, 2006).

3. Em 1891, todos os ministérios situados na Capital Federal já possuíam seus próprios esquemas de seguro organizados para amparar o futuro das famílias dos servidores públicos. A filiação a esses esquemas tinha um caráter compulsório e os benefícios a eles atrelados decorriam de um reconhecimento profissional estabelecido em lei. Portanto, tal filiação era definida como um direito.

4. A visão desses primeiros estatutos de proteção destinados aos funcionários públicos como "privilégios" é reforçada por alguns estudiosos do tema da emergência dos sistemas previdenciários nos países latino-americanos (Malloy, 1976, 1986; Mesa-Lago, 1978).

5. Como apontaram alguns autores, o emprego intensivo de mulheres e crianças nas indústrias paulistas, além de contribuir para a forte depreciação dos salários, dilatava a já superabundante oferta de mão de obra, permitindo que essas indústrias prosperassem com níveis baixíssimos de salários (Beiguelman, 1977; Cano, 1977).

6. Conforme salienta Tânia Regina de Luca (1990) em seu estudo sobre o mutualismo paulista, somente $4,9 \%$ dessas sociedades aliavam os objetivos específicos da mutualização dos riscos à defesa dos direitos dos trabalhadores junto às empresas, e apenas $8,1 \%$ delas se preocupavam, de fato, em dirigir apelos semelhantes ao poder público (Luca, 1990:32).

7. A Revista Cultura Política foi um dos principais veículos de divulgação da obra de legislação social do governo Vargas durante o período do Estado Novo (1937-1945). Apesar do seu notório conteúdo "oficialista", publicaram nessa revista intelectuais das mais variadas correntes de pensamento, como Nelson Werneck Sodré, San Tiago Dantas, Celso Furtado, Almir Andrade (editor da revista), Azevedo Amaral e Guerreiro Ramos. Circulou de março de 1941 a agosto de 1945, tendo cinquenta meses de publicação regular. Suas diversas edições traziam um panorama dos feitos do regime varguista no campo da legislação social, sempre ressaltando a vinculação entre o movimento de sindicalização e de securitização da classe trabalhadora como o principal objetivo a ser perseguido pelo governo Vargas.

8. Em 1933, é criado o Instituto de Aposentadoria e Pensões dos Marítimos - IAPM (Decreto $\mathrm{n}$-22.872, de 29/06/1933). Logo a seguir, em 1934, são organizados o Instituto de Aposentadoria e Pensões dos Comerciários - IAPC (Decreto no 24. 273 de 22/05/1934) e o Instituto de Aposentadoria e Pensões dos Bancários - IAPB (Decreto no 24.615 de 09/06/1934). Em 1938, são criados o Instituto de Aposentadoria e Pensões dos Transportadores de Cargas - IAPTEC e o Instituto de Aposentadoria e Pensões dos Estivadores - IAPE (ambos pelo mesmo Decreto noㅡ 627 de 18/08/1938). 
No mesmo ano, surge o Instituto de Aposentadoria e Pensões dos Industriários IAPI (criado pelo Decreto nํ367, de 31 /12/1936 e regulamentado pelo Decreto-lei 1.918 de 27 /08/1937). Em 1940, é instituído o Instituto de Previdência e Assistência dos Servidores do Estado - IPASE (Decreto-Lei no 2.865 de 12/12/1940).

9. Aqui incluído o próprio Departamento Administrativo do Serviço Público (DASP), instituição criada pelo governo Vargas, em 1938, para imprimir um caráter weberiano ao aparato burocrático do Estado.

10. Cabe aqui salientar que o conflito entre o sindicalismo e a burocracia previdenciária se arrastará até 1967, quando finalmente os IAPs são unificados em uma única instituição, o Instituto Nacional de Previdência Social (INPS). Essa unificação, consumada durante o regime militar (1964-1985), representará o controle da burocracia previdenciária sobre o sindicalismo num contexto autoritário e insulado das pressões políticas.

11. No início dos anos 40, formou-se uma comissão técnica incumbida de estudar a reforma da Lei de Acidentes de Trabalho. Essa comissão buscava criar um Instituto Nacional de Prevenção e de Seguros de Acidentes do Trabalho, dando origem ao Decreto-Lei no 7.036 de 10/11/1944, que transformou as indenizações por acidentes em um seguro social, sem lograr seu grande objetivo que era o de torná-lo público (Cesarino JR., 1970). É somente em 1967 que esses seguros são retirados da tutela das companhias privadas, passando a ser integrados à previdência social.

12. As carteiras de investimentos imobiliários dos IAPs possibilitavam aos seus associados adquirirem casas próprias, em prestações mensais não excedentes a $50 \%$ dos salários, incluídos os juros ( 6 a $8 \%$ ao ano). O prazo estabelecido para a amortização dos empréstimos era de 20 anos (Cultura Política, no 33, 1943:72).

13. Castro Gomes (1988:23) afirma que o êxito do projeto político varguista de incorporação das demandas do trabalho, especialmente durante a vigência do Estado Novo, deve-se ao fato de tal projeto ter ressignificado, mediante a política social e trabalhista, o repertório de ação coletiva e de protesto vocalizado pelas lideranças da classe trabalhadora durante a Primeira República. O importante aqui é perceber como essa ressignificação trouxe consequências duradouras para a vida política e associativa do Estado social brasileiro.

14. Tais medidas tratavam explicitamente de tornar o sindicato profissional "a casa do trabalhador" e o imposto sindical, bem como a CTOS, tornaram-se as iniciativas-chave para conferir densidade às associações sindicais (CASTRO GOMES, 1999, p. 93) A CTOS desempenhou um papel fundamental na promoção da sindicalização, sem a qual os Institutos de Previdência permaneceriam esvaziados de suas prerrogativas.

15. O instituto da estabilidade perdurou no país até 1966, sendo extinto pelas políticas antitrabalho do regime militar (1964-1985). Com o fim do instituto da estabilidade, o empregador viu-se contemplado em seu objetivo de limitar a duração dos contratos de trabalho - o que lhe possibilitou a contratação de trabalho farto, ocasional e barato, tornando cada vez mais difícil a distinção entre o assalariado e o subempregado. Após a extinção do instituto da estabilidade, em 1966, nenhuma medida mais contundente seria tomada pelos governos brasileiros para inibir a demissão imotivada e a intensa rotatividade no mercado de trabalho.

16. Entre 1932 e 1940, Oliveira Vianna foi consultor jurídico do MTIC, convivendo, nessa instituição, ao lado de outros grandes jurisconsultos do trabalho como Evaristo de Moraes, Joaquim Pimenta e Evaristo de Moraes Filho.

DADOS - Revista de Ciências Sociais, Rio de Janeiro, vol. 61, nº 2, 2018 


\section{Arnaldo Provasi Lanzara}

17. É somente em 1971, com o FUNRURAL, que é concedido aos trabalhadores rurais o benefício do seguro social. Mais tarde, talvez como iniciativa de reparação histórica, a Constituição brasileira de 1988 tratará de universalizar o acesso à previdência para os trabalhadores rurais, conferindo-lhes a condição de segurado especial.

18. Segundo estatísticas do período, dos 11.8 milhões de trabalhadores brasileiros, aproximadamente 8.8 milhões estavam empregados em ocupações do setor primário - o que importava em $75 \%$ da população ativa do país (PINHO, 1941:24)

19. As propostas de extensão da legislação social para o campo se acentuaram nos anos finais do Estado Novo. O seguro social foi parcialmente ampliado ao campo, com a cobertura de acidentes de trabalho, através do Decreto-lei 18.809, de 05/06/45. A principal iniciativa, nesse sentido, foi a assinatura, no ano anterior, do Decreto-Lei 7.038, que previa a extensão do direito de sindicalização para os trabalhadores rurais (Dezemone, 2007:180). Entretanto, os obstáculos colocados pelo patronato agrário à sindicalização rural prevaleceram durante todo o período 1945-1964. O movimento de sindicalização do campesinato se altera apenas no início dos anos 1960, durante o governo João Goulart (1961-1964), com a edição do Estatuto do Trabalhador Rural de 1963.

20. Sigo aqui o instigante ensaio de Adalberto Moreira Cardoso (2010). Ao desvendar a trama por traz do conceito de "cidadania regulada" (Santos,1979), Cardoso (2010) afirma que a "consciência de classe" dos trabalhadores brasileiros foi, por muito tempo, a consciência do direito a seus direitos, cuja efetividade esteve sempre em processo, e nesse sentido, foi sempre e renovadamente "utópica" (Cardoso, 2010).

21. Segundo Santos (1979), na "cidadania regulada" os direitos do cidadão estão embutidos na profissão e se restringem ao lugar que ocupa no processo produtivo, tal como reconhecido por lei; são pré-cidadãos, portanto, todos aqueles cuja ocupação a lei desconhece (Santos, 1979:75).

22. Walter Korpi utilizou este termo para explicar como os sistemas de proteção social, em países como a Suécia, dependeram da manutenção de um sistema de barganhas institucionalizadas entre capital e trabalho. Pois, no vértice desse sistema, situavam-se fortes sindicatos ligados aos grandes partidos de massa da classe operária, que asseguravam uma representação monopólica dos seus interesses junto aos seus principais contendores (Korpi, 1983). Contudo, mesmo em países cujo poder sindical era relevante vis-à-vis ao das associações patronais, como na Alemanha, a burocracia desempenhou um papel fundamental em auxiliar os sindicatos a resolver seus problemas de ação coletiva por intermédio da participação dos trabalhadores na administração dos fundos do seguro social (Manow, 1997).

23. Cardoso (2010) ilustra essa frustração de expectativas, que se sucedeu após a montagem do arcabouço da legislação social e trabalhista, com alguns dados sobre as emissões das carteiras de trabalho durante o período 1940-1976. Segundo o autor, nesse período, foram emitidas $150 \%$ mais carteiras de trabalho que o crescimento da PEAe $230 \%$ mais que a expansão dos beneficiários da previdência, comprovando que as promessas em torno dos direitos sociais tinham certa eficácia, à medida que os trabalhadores acreditavam na possibilidade de incorporação no assalariamento formal em consolidação, mas que esta promessa jamais se generalizara para a maioria dos trabalhadores brasileiros, pois o número de habilitados com a carteira de trabalho, no período considerado, foi muito superior ao número dos efetivamente segurados pelo universo protetor da previdência social (Cardoso, 2010:229). 


\section{REFERÊNCIAS BIBLIOGRÁFICAS}

ABRANCHES, Fernando de. (1974), Do Seguro Mercantilista de Acidentes do Trabalho ao Seguro Social. São Paulo, Sugestões Literárias.

BATALHA, Claudio Henrique M. (1999), "Sociedades de Trabalhadores do Rio de Janeiro do Século XIX: Algumas Reflexões em Torno da Formação da Classe Operária". Cadernos do AEL: Sociedades Operárias e Mutualismo, Campinas: Unicamp/IFCH, v.6, no 10/11, pp.41-61. Disponível em http://segall.ifch.unicamp.br/publicacoes_ael/index.php/cadernos_ael/article/view/91/9. Acessado em 22 de julho de 2012.

BEIGUELMAN, Paula. (1977), Os Companheiros de São Paulo. São Paulo, Editora Símbolo.

BOLTANSKI, Luc e THÉVENOT, Laurent. (2006), On Justification: Economies of Worth. Princeton, Princeton University Press.

BOURGEOIS, Léon. (1896), Solidarité. Paris, Armand Colin. Disponível em: http:/ / classiques.uqac.ca/classiques/bourgeoisãleon/solidarite/bourgeoisãsolidarite.pdf

BRASIL.(1923), Decreto no 4.682, de 24 de Janeiro de 1923. Crea, em cada uma das emprezas de estradas de ferro existentes no paiz, uma caixa de aposentadoria e pensões para os respectivos empregados.Presidência da República, Rio de Janeiro. Disponível em http://www.planalto.gov.br/ccivil_03/decreto/Historicos/DPL/DPL4682.htm. Acessado em 11 de março de 2012.

. (1943), Decreto-Lei №5.452, de 1 de Maio de 1943. Aprova a Consolidação das Leis do Trabalho. Presidência da República, Rio de Janeiro. Disponível em http:/ / www.planalto.gov.br/ccivil_03/decreto-lei/Del5452.htm. Acessado em 11 de março de 2012.

CANO, Wilson. (1977), Raízes da Concentração Industrial em São Paulo. São Paulo, Difel.

CARDOSO, Adalberto M. (2010), A Construção da Sociedade do Trabalho no Brasil. Uma Investigação sobre a Persistência Secular das Desigualdades. Rio de Janeiro, Editora FGV.

CARVALHO, José M. de. (1985), “República e Cidadanias”. Dados - Revista de Ciências Sociais, Rio de Janeiro, vol.28, № 2, pp.143-161.

CASTEL, Robert. (1998), As Metamorfoses da Questão Social. Uma Crônica do Salário. Petrópolis,Vozes.

(2003), L'Insécurité Sociale. Qu'est-ce qu'être protégé? Paris, Seuil.

e HAROCHE, Claudine. (2001), Propriété Privée, Propriété Social, Propriété de Soi. Paris, Fayard.

CASTRO, Araújo. (1935), Accidentes do Trabalho. Rio de Janeiro, Editora Freitas Bastos.

CASTRO GOMES, Angela M. de. (1979), Burguesia e Trabalho. Política e Legislação Social no Brasil 1917-1937. Rio de janeiro, Editora Campus.

(1988), A Invenção do Trabalhismo. Rio de Janeiro, Vértice/IUPERJ.

. (1999), "Ideologia e Trabalho no Estado Novo". in D. Paldolfi (org.), Repensando o Estado Novo. Rio de Janeiro, Editora FGV.

CESARINO, JR. Antonio F. (1970), Direito Social Brasileiro. Vol. I. São Paulo, Saraiva.

DADOS - Revista de Ciências Sociais, Rio de Janeiro, vol. 61, nº 2, 2018 


\section{Arnaldo Provasi Lanzara}

COSTA, Wanda M. R. (1999), A Armadilha do Leviatã. A Construção do Corporativismo no Brasil. Rio de Janeiro, Editora UERJ.

CULTURA POLÍTICA. (1941), "Previdência e Assistência Social no Decênio Getúlio Vargas". Cultura Política: Revista Mensal de Estudos Brasileiros, no 9, nov., pp. 290-302.

. (1942), “O Ministério do Trabalho, Indústria e Comércio no Qüinqüênio 1937-1942". Cultura Política: Revista Mensal de Estudos Brasileiros, no21, nov., pp.38-53.

. (1943), “O Estado Nacional e o Problema das Casas Operárias". Cultura Política: Revista Mensal de Estudos Brasileiros, no 33, out., pp. 73-82.

. (1944a), "Assistência e Previdência Social no Estado Nacional". Cultura Política: Revista Mensal de Estudos Brasileiros, no 46, nov., pp. 10-30.

. (1944b), "Reportagem entre os Trabalhadores sobre os Benefícios da Legislação Social". Cultura Política: Revista Mensal de Estudos Brasileiros, no 46, nov., pp.68-78.

LUCA, Tânia R. de. (1990), O Sonho do Futuro Assegurado: O Mutualismo em São Paulo. São Paulo, Contexto.

DEZEMONE, Marcos. (2007), “Impactos da Era Vargas no Mundo Rural: Leis, Direitos e Memória", Revista Perseu, no 1, ano 1, p. 177-205.

DINIZ, Eli R. e BOSCHI, Renato R. (1991), “O Corporativismo na Construção do Espaço Público", in R. R. Boschi (org.), Corporativismo e Desigualdade. A Construção do Espaço Público no Brasil. Rio de Janeiro, Rio Fundo Editora/IUPERJ.

DURHAM, Eunice R. (1973), A Caminho da Cidade. A Vida Rural e a Migração para São Paulo. São Paulo, Perspectiva.

ESPING-ANDERSEN, Gøsta. (1990), The Three Worlds of Welfare Capitalism. Princeton, Princeton University Press.

EWALD, François. (1986), L'Etat Providence. Paris, Grasset. . (1990), "La Société Assurancielle". Risques - Les Cahiers de L`Assurance, no 1, pp. 1-23.

(1992), “Responsabilité - Solidarité - Securité. La Crise de la Responsabilité en France à la Fin du XX Siècle”. Risques - Les Cahiers de L'Assurance, no 10, pp. 09-24.

FERREIRA, Jorge. (1997), Trabalhadores do Brasil. O Imaginário Popular. Rio de Janeiro, Editora FGV.

FREITAS, Bezerra de. (1942), “A Missão Nacional das Instituições de Previdência”. Cultura Política: Revista Mensal de Estudos Brasileiros. no 13, mar., pp.160-165.

GUIMARÃES, Nadia A. (2015), "Mercado e Mercantilização do Trabalho no Brasil”, in M. Arretche (org.). Trajetória das Desigualdades. Como o Brasil Mudou nos Últimos Cinquenta Anos. São Paulo, Editora Unesp/Centro de Estudos da Metrópole, pp.395-421.

HATZFELD, Henri. (1982), "La Difficile Mutation de la Sécurité-Propriété à la Sécurité-Droit'. Prévenir, no 5, mar, p. 22-46.

HOCHMAN, Gilberto. (1992), “Os Cardeais da Previdência Social: Gênese e Consolidação de uma Elite Burocrática". Dados - Revista de Ciências Sociais, Vol.3, no 3, pp. 371-401.

KORPI, Walter. (1983), The Democratic Class Struggle. London, Routledge. 
LANZARA, Arnaldo P. (2012), A Construção Histórica do Estado Social no Brasil e no Chile: Do Mutualismo ao Seguro. Tese (Doutorado em Ciência Política), Instituto de Estudos Sociais e Políticos/Universidade do Estado do Rio de Janeiro - IESP/UERJ, Rio de Janeiro.

LOPES, Juarez B. (1964), Sociedade Industrial no Brasil. São Paulo, Difusão Europeia do Livro.

LOUZADA, Alfredo J. (1990[1933]), Legislação Social-Trabalhista: Coletânea de Decretos Feita por Determinação do Ministro do Trabalho, Indústria e Comércio. 2. ed. Brasília, MTPS.

LUHMANN, Niklas. (1983), Sociologia do Direito, V. I e II. Rio de Janeiro, Tempo Brasileiro.

MALLOY, James. (1976), “A Política de Previdência Social no Brasil: Participação e Paternalismo". DADOS-Revista de Ciências Sociais, no 13, pp.93-100.

. (1986), A Política de Previdência Social no Brasil. Rio de Janeiro, Graal.

MANOW, Philip. (1997), "Social Insurance and the German Political Economy". Max Planck Institute for the Study of Societies. Discussion Paper 97, 2, pp. 2-48. Disponível em https://www.econstor.eu/dspace/bitstream/10419/43178/1/236715429.pdf. Acessado em 17 de novembro de 2011.

MENESES, Djacir. (1943), "Contribuição Brasileira para a Paz no Mundo de Amanhã", Cultura Política: Revista Mensal de Estudos Brasileiros, no 31, ago., pp. 330-339.

MESA-LAGO, Carmelo. (1978), Social Security in Latin America: Pressure Groups, Stratification and Inequality. Pittsburgh, University of Pittsburgh Press.

MORAES FILHO, Evaristo de. (1978), O Problema do Sindicato Único no Brasil: seus fundamentos sociológicos. São Paulo, Alfa-Omega.

OLIVEIRA VIANNA, Francisco José de. (1938), Problemas de Direito Corporativo. Rio de Janeiro, José Olympio.

. (1951), Direito do Trabalho e Democracia Social: O Problema da Incorporação do Trabalho no Estado. Rio de Janeiro, José Olympio.

PIMENTA, Joaquim. (1935), “Direito Sindical Brasileiro". Revista do Trabalho, no 22, p. 02-23.

PINHEIRO, Paulo S. (2006), "O Proletariado Industrial na Primeira República", in B. Fausto (org.). História Geral da Civilização Brasileira. Tomo III. O Brasil Republicano. Rio de Janeiro, Bertrand Brasil.

PINHO, Péricles M. de. (1941), "A Legislação Social e a Agricultura". Cultura Política: Revista Mensal de Estudos Brasileiros, no 6, ago., pp. 20-26.

PIZZORNO, Alessandro. (1967), “Sul Metodo di Gramsci. Dalla Storiografia alla Scienza Politica". Quaderni di Sociologia, no 4, pp. 380-400.

REIS, Fabio W. (2009), Mercado e Utopia. Rio de Janeiro, Centro Edelstein de Pesquisas Sociais.

ROSANVALLON. Pierre. (2008), La Légitimité Démocratique. Impartialité, Réflexivité, Proximité. Paris, Seuil.

SANTA ROSA, Virgínio. (1976 [1933]), O Sentido do Tenentismo. São Paulo, Alfa-Omega.

DADOS - Revista de Ciências Sociais, Rio de Janeiro, vol. 61, n² 2, 2018 


\section{Arnaldo Provasi Lanzara}

SANTOS, Wanderley G. dos. (1979), Cidadania e Justiça. A Politica Social na Ordem Brasileira. Rio de Janeiro, Editora Campus.

SEGADAS VIANA, José de. (1943), A Organização Sindical Brasileira. Rio de Janeiro, O Cruzeiro.

SUPIOT, Alain. (1994), Critique du Droit du Travail. Paris, PUF.

SWAAN, Abram de. (1988), In Care of the State. Health Care, Education and Welfare in Europe an USA in the Modern Era. Cambridge, Polity Press.

. (2005), "Mutual Funds: Then and here, now and there. Informal savings and insurance funds in the nineteenth-century west and the present non-western world", in A. De Swann e M. Van Der Linden (eds.), Mutualist Microfinance. Informal Savings Funds from the Global Periphery to the Core? Amsterdam, Aksant.

THOMPSON, Edward P. (1968), The Making of the English Working Class. London, Penguin Books.

TITMUSS, Richard. (1963), Essays on the Welfare State. London, George Allen \& Unwin.

TOCQUEVILLE, Alexis de. (1989[1835]), Memoir sur le Pauperisme. Oeuvres Complètes. Paris, Gallimard.

(2000 [1840]), A Democracia na América. Sentimentos e Opiniões. São Paulo, Martins Fontes.

WERNECK VIANNA, Luiz. (1999[1976]), Liberalismo e Sindicato no Brasil. Belo Horizonte, UFMG. 
RESUMO

O Seguro Social e a Construção da Proteção do Trabalho no Brasil

A função protetora do seguro social mostrou-se fundamental em estabilizar as expectativas dos assalariados quanto à manutenção das condições de sua independência social, constituindo-se numa propriedade para a segurança das coletividades fortemente imbricada à ideia de pertencimento coletivo. Por portar tais características, o seguro social desempenhou um importante papel em sociedades estruturalmente desiguais e caracterizadas por certa rarefação de organizações coletivas vinculadas ao trabalho. Este estudo demonstra como a regulação do mercado de trabalho brasileiro, desde sua origem, dependeu dos benefícios do seguro social para fixar as expectativas do trabalhador em torno da sua inscrição no assalariamento formal. A hipótese a ser aventada, neste estudo, é que as elites estatais brasileiras, responsáveis por implementar a política social e trabalhista nas décadas de 1930 e de 1940, se utilizaram deliberadamente desses benefícios como estratégia de indução institucional para adensar a base de organização dos sindicatos e ampliar o alcance da legislação social.

Palavras-chave: seguro social; trabalho; Brasil; sindicatos; legislação social.

\section{ABSTRACT}

Social Security and the Construction of Labor Protection in Brazil

The protective function of social insurance has proved to be fundamental in stabilizing the expectations of the wage-earners as to the maintenance of the conditions of their social independence, constituting a property for the security of the collectivities strongly imbricated to the idea of ??collective belonging. Because it has such characteristics, social insurance has played an important role in societies structurally unequal and characterized by a certain rarefaction of collective organizations linked to work. This study demonstrates how the regulation of the Brazilian labor market, from its origin, depended on the benefits of social insurance to set the expectations of the worker around their enrollment in formal employment. The hypothesis to be put forward in this study is that Brazilian state elites, responsible for implementing social and labor policy in the 1930s and 1940s, have deliberately used these benefits as an institutional induction strategy to broaden the organization base of unions and expand the scope of social legislation.

Keywords: social security; work; Brazil; trade unions; social legislation.

DADOS - Revista de Ciências Sociais, Rio de Janeiro, vol. 61, n² 2, 2018 
RESUMEN

El Seguro Social y la Construcción de la Protección del Trabajo en Brasil

La función protectora del seguro social es fundamental para estabilizar las expectativas de los asalariados en lo que se refiere a la manutención de las condiciones de su independencia social, constituyéndose en un eje clave para la seguridad de las colectividades y para la idea de pertenencia colectiva. Debido a estas atribuciones, el seguro social ha desempeñado un rol importante en sociedades estructuralmente desiguales caracterizadas por cierta rarefacción de organizaciones colectivas vinculadas al trabajo. Este artículo demuestra cómo la regulación del mercado laboral brasileño dependió, desde su origen, de los beneficios del seguro social para fijar las expectativas del trabajador alrededor de su inscripción en el salario formal. La hipótesis sugerida es que las elites estatales brasileñas, responsables por implementar la política social y laboral en las décadas de 1930 y 1940, se utilizaron deliberadamente de esos beneficios como estrategia de inducción institucional para adensar la base de organización de los sindicatos y ampliar, a la vez, el alcance de la legislación social.

Palabras-clave: seguro social; trabajo; Brasil; sindicatos; legislación social. 